\title{
Analysis and Selective Treatment of Radioactive Waste Waters and Sludges
}

\author{
György Pátzay¹, László Weiser¹, Ferenc Feil² and Gábor Patek² \\ ${ }^{1}$ Budapest University of Technology and Economics \\ 2Paks Nuclear Power Plant
}

Hungary

\section{Introduction}

In the Hungarian PWR-type nuclear power plant Paks (four $500 \mathrm{MW}_{\mathrm{e}}$ capacity VVER$440 / 213$ blocks) the radioactive waste waters are collected in common tanks. These water streams contain radioactive isotopes in ultra-low concentration and inactive compounds as major components (borate $1.7 \mathrm{~g} / \mathrm{dm}^{3}$, sodium-nitrate $0.4 \mathrm{~g} / \mathrm{dm}^{3}$, sodium-hydroxide 0.16 $\mathrm{g} / \mathrm{dm}^{3}$, and oxalate $\left.0.25 \mathrm{~g} / \mathrm{dm}^{3}\right)$.

Up to the present the low salinity solutions were evaporated (by adding sodium-hydroxide) till $400 \mathrm{~g} / \mathrm{dm}^{3}$ salt content $(\mathbf{p H} \sim \mathbf{1 3})$ and after solidification by cementing buried. There is about $6000 \mathrm{~m}^{3}$ concentrated evaporator bottom residue in the tanks of the PWR. In order to separate the inactive salt content before cementing a Liquid Wastewater Treatment Technology (LWT see Figure 1.) was developed to treat this wastewater before solidification and burial (Pátzay et al., 2006).

The long-life radionuclides are present in very low concentration $\left(10^{-9}-10^{-12} \mathrm{~mol} / \mathrm{dm}^{3}\right)$ as ions, suspended, colloid particles and in complex (EDTA, oxalate, citrate) form. In this technology the SELION CsTreat cesium selective ion exchanger is used for the selectice separation of radiocesium isotopes $\left({ }^{134} \mathrm{Cs},{ }^{137} \mathrm{Cs}\right)$. The SELION CsTreat cyanoferrate based cesium-selective ion exchanger is not stable at $\mathrm{pH}>11$ (see reaction equation below), so the use of CsTreat needs partial neutralisation of the evaporator bottom residue to $\mathrm{pH}$-9-11, and during neutralisation sodium-borate crystals precipitate with about $15-30 \%$ of the radioactivity.

$$
\mathrm{K}_{2} \mathrm{Co}\left[\mathrm{Fe}(\mathrm{CN})_{6}\right]+2 \mathrm{OH}^{-} \Rightarrow 2 \mathrm{~K}^{+}+\left[\mathrm{Fe}(\mathrm{CN})_{6}\right]^{4-}+\mathrm{Co}(\mathrm{OH})_{2}
$$

The contaminated crystals should be washed to remove the radioactive isotopes from the crystals. To eliminate the generation of radioactive borate crystals and additional wastes we have developed a $\mathrm{M}_{2} \mathrm{Ni}\left[\mathrm{Fe}(\mathrm{CN})_{6}\right]$ type cesium selective granulated ion exchanger (where $\mathrm{M}$ is an alkali ion) which has good stability even at $\mathrm{pH}>11$.

Based on this new cesium selective ion exchanger stable at $\mathrm{pH}>11$ we have modified the radioactive evaporator bottom residue treatment technology at the nuclear power plant. The basic idea of the new technological scheme is the selective separation of all radionuclides with inorganic sorbent materials or reagents in very simple processes without any prior neutralization, dilution. After the separation of all radionuclides the inorganic salt content 


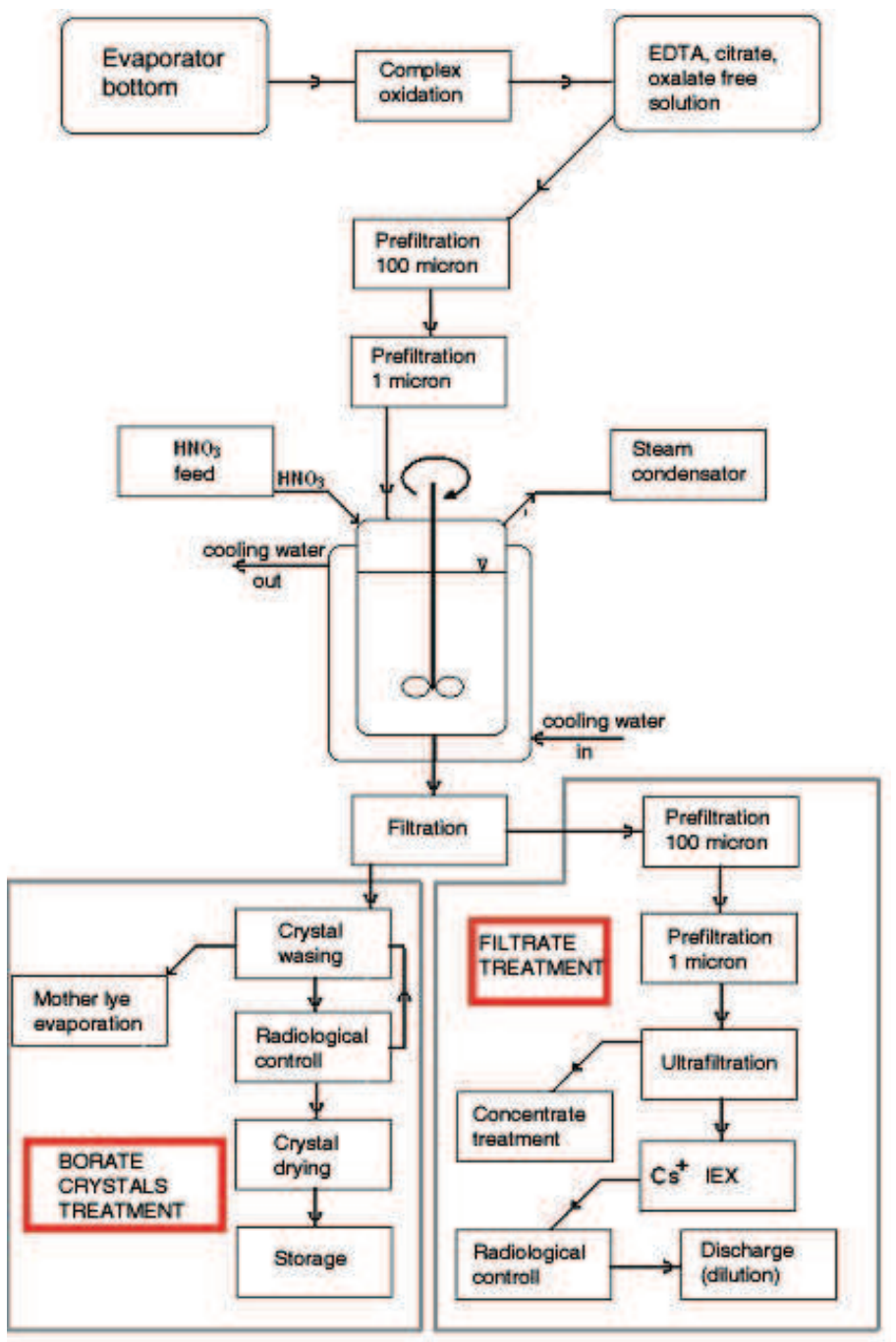

Fig. 1. The Liquid Wastewater Treatment Technology

(borates, partially nitrates) could be separated with crystallization using nitric acid neutralization and the inactive crystals could be treated as chemical waste. In the first part of this report this modified separation technology will be discussed.

In the Nuclear Power Plant Paks at the bottom of some radioactive liquid waste containing tanks there are segregated sludge phases, containing more or less organic complex builder compounds (including EDTA, citrate and oxalate compounds). The radioactive waste water treatment technology, developed at the plant is not suitable to treat sludges, so a modified technology is needed using cementing as solidification. For this technology the detailed analysis of these sludge phases are of great importance. According to this problems we started a research work to investigate the international experience in the analysis of 
radioactive sludges and fulfilled laboratory scale experiments for chemical and radiochemical analysis of different sludge samples. In the second part of this report the analysis of these radioactive sludges will be discussed.

\section{The modified liquid wastewater treatment technology}

The developed modified technology consists of the following parts:

- Firstly the high salt content, strongly alkaline $(p H \sim 13-14)$ evaporator bottom residue is microfiltered.

- Then the free EDTA, citrate, oxalate content is oxidized with underwater plasma torch and with Fenton oxidation (in this process Co isotopes removed by precipitation as oxide-hydroxide and can be separated by filtration). The treated solution is microfiltered and ultrafiltered.

- $\quad$ Selective separation of the radioactive cesium isotopes $\left({ }^{137} \mathrm{Cs},{ }^{134} \mathrm{Cs}\right)$ using ion exchange material stable at alkaline $\mathrm{pH}$.

- Crystallization of borates from the mother lye by neutralization with nitric acid.

The modified waste treatment technology was tested at the NPP. After microfiltration about $500 \mathrm{dm}^{3}$ evaporator bottom residue was oxidized with underwater plasma torch for the EDTA, citrate and oxalate removal. The oxidized evaporator bottom residue was then microfiltered and ultrafiltered to remove suspended matter and cobalt precipitation from the solution having a $\mathrm{pH} \sim 12.3$ The separation efficiency of the ultrafiltration is shown in Table 1.

\begin{tabular}{|c|c|c|c|c|c|c|}
\hline & $\begin{array}{c}{ }^{60} \mathrm{Co} \\
\text { activity } \\
\text { concentration } \\
(\mathrm{Bq} / \mathrm{kg})\end{array}$ & $\%$ & $\begin{array}{c}{ }^{134} \mathrm{Cs} \\
\text { activity } \\
\text { concentration } \\
(\mathrm{Bq} / \mathrm{kg})\end{array}$ & $\%$ & $\begin{array}{c}{ }^{137} \mathrm{Cs} \\
\text { activity } \\
\text { concentration } \\
(\mathrm{Bq} / \mathrm{kg})\end{array}$ & $\%$ \\
\hline Feed & 2310 & 100 & 1350 & 100 & 181000 & 100 \\
\hline Permeate & 258 & 11.2 & 1210 & 89.6 & 164000 & 90.6 \\
\hline
\end{tabular}

Table 1. Ultrafiltration of the waste water after oxidation of the complex compounds

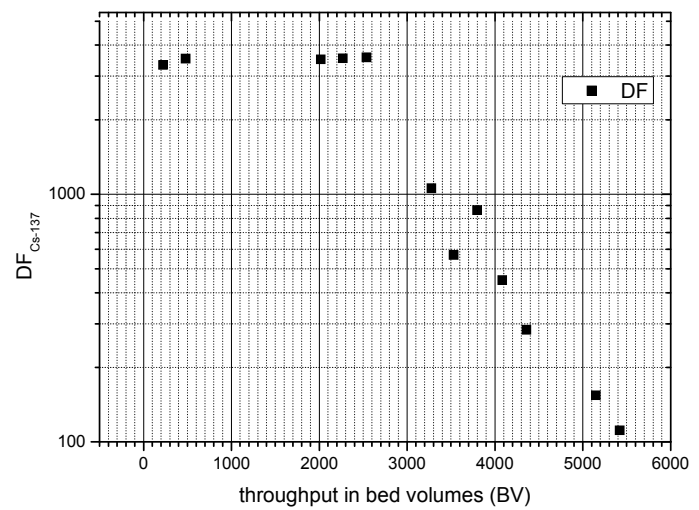

Fig. 2. Breakthrough curve of ${ }^{137} \mathrm{Cs}$ (BV-bed volume) 
The solution purified from radioactíve cesium was then acidified with concentrated nitric acid in $20 \mathrm{dm}^{3}$ batches in a cooled mixed reactor till $\mathrm{pH}$ 9.0. The crystallization reactor is shown in Figure 3.

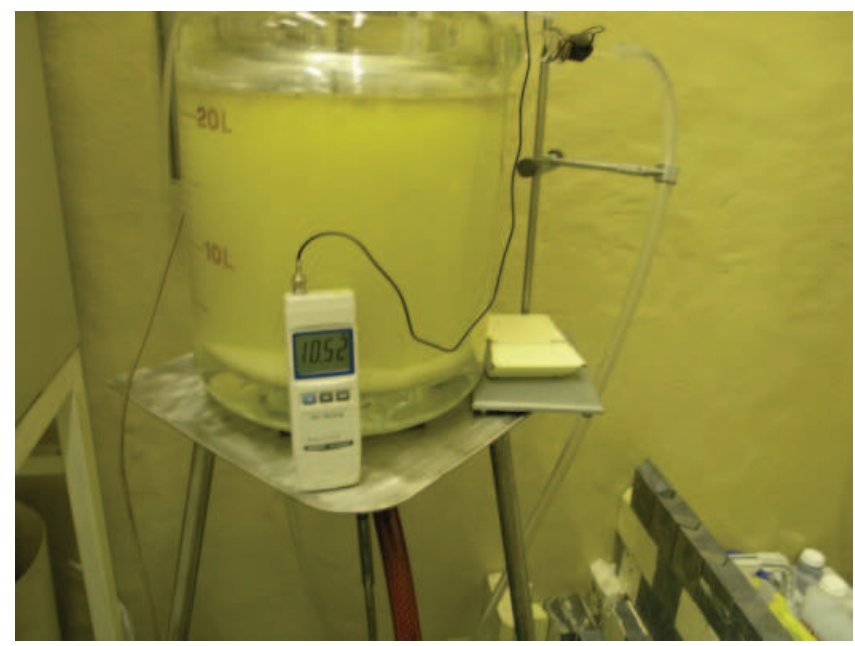

Fig. 3. The crystallyzation reactor

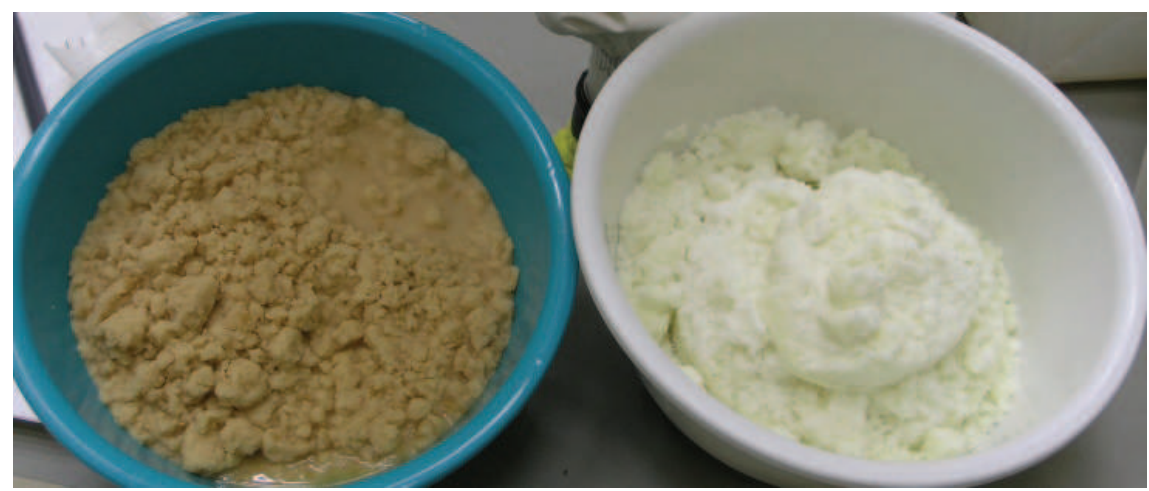

Fig. 4. The separated wet crystals by the original (left) and by the modified (right) technology

The crystals were separated by filtration, dried at $50{ }^{\circ} \mathrm{C}$ and weighted. The crystalline product contained mainly sodium-metaborate $\left(\mathrm{NaBO}_{2} * 8 \mathrm{H}_{2} \mathrm{O}\right)$. Heating the product above $55{ }^{\circ} \mathrm{C}$ the crystalline phase released four water molecules and $\mathrm{NaBO}_{2} * 4 \mathrm{H}_{2} \mathrm{O}$ formed. Figure 4 shows the separated wet crystals by the original and by the modified technology.

The measured specific radioactivity of the separated, dried crystalls and the unconditional clearance limit values are summarized in Table 2. 


\begin{tabular}{|c|c|c|}
\hline Radionuclide & Measured specific activity (Bq/g) & Unconditional clearance limit $(\mathrm{Bq} / \mathrm{g})$ \\
\hline${ }^{51} \mathrm{Cr}$ & $1.42 \mathrm{E}-02$ & 30 \\
\hline $54 \mathrm{Mn}$ & 1.19E-03 & 1 \\
\hline${ }^{58} \mathrm{Co}$ & $1.01 \mathrm{E}-03$ & 1 \\
\hline${ }^{59} \mathrm{Fe}$ & $1.93 \mathrm{E}-03$ & 0.9 \\
\hline${ }^{60} \mathrm{Co}$ & $1.17 \mathrm{E}-03$ & 0.9 \\
\hline $65 \mathrm{Zn}$ & $2.66 \mathrm{E}-03$ & 2 \\
\hline $95 \mathrm{Nb}$ & $1.10 \mathrm{E}-03$ & 0.9 \\
\hline $95 \mathrm{Zr}$ & $1.81 \mathrm{E}-03$ & 3 \\
\hline${ }_{106} \mathrm{Ru}$ & $1.15 \mathrm{E}-02$ & 1 \\
\hline $110 \mathrm{~m} A g$ & $1.83 \mathrm{E}-03$ & 0.9 \\
\hline $124 \mathrm{Sb}$ & $1.83 \mathrm{E}-03$ & 0.9 \\
\hline${ }^{125} \mathrm{Sb}$ & 7.63E-03 & 1 \\
\hline${ }^{134} \mathrm{Cs}$ & $1.66 \mathrm{E}-03$ & 0.9 \\
\hline${ }^{137} \mathrm{Cs}$ & 1.11E-01 & 2 \\
\hline${ }^{144} \mathrm{Ce}$ & $1.02 \mathrm{E}-02$ & 30 \\
\hline${ }^{154} \mathrm{Eu}$ & 2.59E-02 & 0.9 \\
\hline${ }^{3} \mathrm{H}$ & 2.94E-02 & 2000 \\
\hline${ }^{14} \mathrm{C}$ & 1.91E-05 & 200 \\
\hline${ }^{55} \mathrm{Fe}$ & 3.01E-05 & 100 \\
\hline${ }^{59} \mathrm{Ni}$ & $6.20 \mathrm{E}-06$ & 800 \\
\hline $63 \mathrm{Ni}$ & $2.72 \mathrm{E}-04$ & 300 \\
\hline $90 \mathrm{Sr}$ & $3.19 \mathrm{E}-02$ & 1 \\
\hline 99Tc & 7.19E-05 & 1 \\
\hline 129I & $1.24 \mathrm{E}-09$ & 0.9 \\
\hline $234 \mathrm{U}$ & $4.69 \mathrm{E}-07$ & 0.9 \\
\hline $235 \mathrm{U}$ & $1.71 \mathrm{E}-07$ & 0.9 \\
\hline $238 \mathrm{U}$ & $1.09 \mathrm{E}-07$ & 0.9 \\
\hline $238 \mathrm{Pu}$ & $4.83 \mathrm{E}-07$ & 0.9 \\
\hline $239,240 \mathrm{Pu}$ & 3.62E-07 & 0.9 \\
\hline $241 \mathrm{Am}$ & $5.48 \mathrm{E}-08$ & 0.9 \\
\hline${ }^{242} \mathrm{Cm}$ & 4.01E-07 & 0.9 \\
\hline${ }^{244} \mathrm{Cm}$ & $4.26 \mathrm{E}-07$ & 0.9 \\
\hline
\end{tabular}

Table 2. The measured specific radioactivity of the separated, dried crystalls and the unconditional clearance limit values

Based on our modification of the original wastewater treatment technology in the Hungarian Nuclear Power Plant we get beneficial results summarized as follows:

- The use of the new cesium selective ion exchanger eliminates the acidification of the evaporator bottom residue before the cesium removal by ion exchange.

- Hence we can avoid the formation of borate crystals contaminated with radionuclides of cesium etc. and the additional washing of the separated crystals for the radioactivity removal.

- According to measured specific activity data we are able to release the dried solid crystals from the NPP and could be used as non-radioactive borate chemical. 


\section{Chemical and radiochemical analysis of radioactive sludges fron NPP Paks}

According to the international experiences the sampling process depends on the sludge characteristics. The first step of the sampling process is a previous sampling to determine the boundary between the supernatant and sludge layers. This is followed after 3-4 days by the sampling. For diluted, liquid type sludges below the supernatant layer we can detect very often a crystalline salt and amorf sludge layer too. Sampling are usually done from the top, intermediate and bottom layers using a sampling pipe and vacuum For the concentrated sludges the samples are taken from different layers of the sludge phase.

Following the sampling the sludge samples are photographed and characterized. The samples for organic content determination (TC, TOC, TIC) are collected in glass bottles, the samples for ion chromatographic analysis are stored in polyethylene botles at $4{ }^{\circ} \mathrm{C}$. The liquid samples are analysed for $\mathrm{pH}$.

We investigated two times three sludge samples taken from the tanks 02TW30B001, 02TW01B001, 01XZ06B001 of the Paks NPP. The sample characteristics are summerized in Table 3.

\begin{tabular}{|c|c|c|c|}
\hline $\begin{array}{c}\text { Sample } \\
\text { Code }\end{array}$ & Tank code & Sample type & Sampling time \\
\hline P3 & 02TW30B001 & sludge from the evaporator, $\mathrm{pH} 13$ & $2008.11 .06 .11: 45$ \\
\hline P4 & 02TW01B001 & $\begin{array}{c}\text { settled sludge from diluted waste } \\
\text { water tank, } \mathrm{pH} \sim 8\end{array}$ & 2008.11 .06 .11 .45 \\
\hline P5 & 01 XZ06B001 & sludge from the wash-house waste & 2008. 11. 07. 10.30 \\
\hline P3-2 & 02TW30B001 & sludge from the evaporator, $\mathrm{pH} \mathrm{13}$ & 2009.01 .20$. \\
\hline P4-2 & 02TW01B001 & $\begin{array}{c}\text { settled sludge from diluted waste } \\
\text { water tank, pH 8 }\end{array}$ & 2009.01 .20$. \\
\hline P5-2 & 01 XZ06B001 & sludge from the wash-house waste & 2009.01 .20$. \\
\hline
\end{tabular}

Table 3. Sludge sample characteristics

The samples P3 and P4 are seen on Picture 1. The P3 and P4 samples contained liquid phase too, while sample P5 contained only solid, consistent type phase.
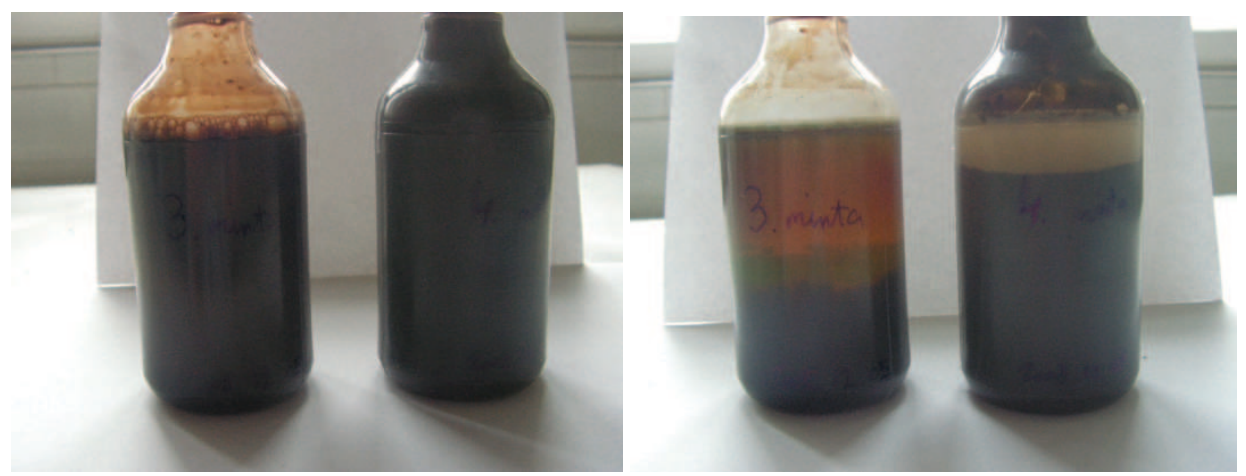

Picture 1. The samples P3 and P4 shaked(left) and settled(right) 


\section{Physical chracateristics of the sludge samples}

Because of the high dissolved and suspended content, high $\mathrm{pH}$ and other characteristics the direct determination of the sludge densities, the total solid content (TS), the dissolved and undissolved solid content (DS, UDS) was questionable. Separation of the liquid content of the composite sludge samples by vacuum filtration resulted a given amount of liquid phase remaining between the particles of the sludge sample and the determination of the total solid content of the sample is also problematic. Washing the dried sample may cause some dissolution losses. Because the above mentioned reasons we used an indirect method suggested by analysts (Ceo et al.,1990) for the determination of the densities and solid content of the samples. The results are shown in Table 4.

\begin{tabular}{|c|c|c|c|c|c|c|c|c|}
\hline & \multicolumn{4}{|c|}{ original sludge } & \multicolumn{4}{c|}{ centrifuged sludge } \\
\hline Sample & DS $^{*}$ & liquid mass & $\mathrm{UDS}^{* *}$ & $\begin{array}{c}\text { flocculation } \\
\text { density }\end{array}$ & DS $^{*}$ & liquid mass & UDS & $\begin{array}{c}\text { flocculation } \\
\text { density }\end{array}$ \\
\hline & $\%$ & $\mathrm{~g} / \mathrm{ml}$ & $\%$ & $\mathrm{~g} / \mathrm{ml}$ & $\%$ & $\mathrm{~g} / \mathrm{g}$ & $\%$ & $\mathrm{~g} / \mathrm{ml}$ \\
\hline $\mathbf{P 3 - 2}$ & 20.417 & 0.971 & 10.174 & 1.139 & 15.022 & 0.847 & 24.415 & 1.179 \\
\hline P4-2 & 0.121 & 0.818 & 18.274 & 1.208 & 0.065 & 0.772 & 22.851 & 1.355 \\
\hline P5-2 & - & - & - & - & - & - & - & - \\
\hline
\end{tabular}

( ${ }^{*}$ DS-dissolved solid content, ${ }^{*}$ UDS-undissolved solid content, floculation density-undissolved solid density)

Table 4. Physical charactersitsics of the sludge samples P3-2, P4-2 and P5-2

\section{Organic content of the samples}

We determined the TOC, TC and COD values of the centrifuged at $4000 \mathrm{~g}$ supernatant portion of the samples P3-2 and P4-2, characterizing the dissolved organic content of the sludge samples. For the TC and TOC determination we used a SHIMADZU OceaniaTOC-V CS device, and COD was determined by the potassium bicromate method using potassiumhydrogen-phtalate reference. Results are seen in Table 5.

\begin{tabular}{|c|c|c|c|c|c|}
\hline Sample & dilution & COD & TC & TIC & TOC \\
\hline & & $\mathrm{mg} / 1$ & $\mathrm{mg} / 1$ & $\mathrm{mg} / 1$ & $\mathrm{mg} / 1$ \\
\hline P3-2 & 100 & 3785 & 5271 & 4177 & 1094 \\
\hline P4-2 & 100 & 971.8 & 250.5 & 140.1 & 110.3 \\
\hline
\end{tabular}

Table 5. Organic content of the centrifuged supernatants

It is seen that sample P3-2 contains higher organic content then sample P4-2.

\section{Chemical composition}

Samples P3-2 and P4-2 contained supernatant liquid, which was separated by centrifuging at $4000 \mathrm{~g}$ for 15 minutes and the separated liquid phase was analysed for anions (fluoride, chloride, nitrate, phosphate and sulfate) and for cations (lithium, sodium, potassium, ammonium, calcium and magnesium), by ion chromatography with dilution factors between 100 and 1000. We used an IC 861 Metrohm type ionchromatograph with a conductometric detector using an Asupp4-250 type anion, and a C3-250 type cation exchanger columns, with a Metrohm 837 type degasser and a Metrohm 838 type sampler. 
Alkalinity (hydroxide, carbonate and hydrogen-carbonate) was determined by titrimetry. Result of the supernatant chemical analysis of samples P3-2 and P4-2 are shown in Table 6.

\begin{tabular}{|c|c|c|c|c|c|}
\hline \multicolumn{6}{|c|}{ P3-2 } \\
\hline \multicolumn{3}{|c|}{ Cations } & \multicolumn{3}{|c|}{ Anions } \\
\hline & $\mathrm{mg} / \mathrm{l}$ & mekv/1 & & $\mathrm{mg} / 1$ & mekv/l \\
\hline $\mathrm{Na}$ & 70389.60 & 3354.9 & $F$ & 46.27 & 2.67 \\
\hline $\mathrm{NH}_{4}$ & 0 & 0 & $\mathrm{Cl}$ & 346.16 & 10.69 \\
\hline $\mathrm{K}$ & 4021.67 & 112.69 & $\mathrm{NO}_{3}$ & 27094.24 & 478.80 \\
\hline $\mathrm{Mg}$ & 0 & 0 & $\mathrm{PO}_{4}$ & 199.77 & 6.92 \\
\hline $\mathrm{Ca}$ & 0 & 0 & $\mathrm{SO}_{4}$ & 1170.01 & 26.69 \\
\hline \multirow[t]{2}{*}{$\mathrm{Mn}$} & 0 & 0 & $\mathrm{OH}$ & 20199.16 & 1301.19 \\
\hline & & & $\mathrm{CO}_{3}$ & 44809.96 & 1636.66 \\
\hline Sum & 74411.27 & 3467.59 & Sum & 93865.58 & 3463.64 \\
\hline \multicolumn{6}{|c|}{ P4-2 } \\
\hline \multicolumn{3}{|c|}{ Cations } & \multicolumn{3}{|c|}{ Anions } \\
\hline & $\mathrm{mg} / \mathrm{l}$ & mekv/l & & $\mathrm{mg} / 1$ & mekv/l \\
\hline $\mathrm{Na}$ & 311.2 & 13.53 & $F$ & 0 & 0 \\
\hline $\mathrm{NH}_{4}$ & 0 & 0 & $\mathrm{Cl}$ & 8 & 0.22 \\
\hline $\mathrm{K}$ & 0 & 0 & $\mathrm{NO}_{3}$ & 40 & 0.64 \\
\hline $\mathrm{Mg}$ & 0 & 0 & $\mathrm{PO}_{4}$ & 12.2 & 0.38 \\
\hline $\mathrm{Ca}$ & 0 & 0 & $\mathrm{SO}_{4}$ & 3.7 & 0.08 \\
\hline \multirow[t]{3}{*}{$\mathrm{Mn}$} & 0 & 0 & $\overline{\mathrm{OH}}$ & 0 & 0 \\
\hline & & & $\mathrm{CO}_{3}$ & 263.67 & 8.79 \\
\hline & & & $\mathrm{HCO}_{3}$ & 289.70 & 4.75 \\
\hline Sum & 311.2 & 13.54 & Sum & 617.27 & 14.87 \\
\hline
\end{tabular}

Table 6. Chemical analysis of the centrifuged supernatants of samples P3-2 and P4-2

It is seen from the ionic composition of the supernatants, that in the P3-2 sample sudium is the main cation and important anions are carbonate, hydrogencarbonate and hydroxide. P42 supernatant sample contains only small amount of sodium and hydrogencarbonate ions.

The chemical composition of the remaining after centrifugation solid phases and of the sample P5-2 was determined by simultaneous wasing water analysis and fusion of the solid phases using potassium-hydroxide fusion and hydrochloric acid dissolution and sodiumperoxyde-sodium-hdroxide fusion and hydrochlorid acid dissolution. Washing was completed by washing $1 \mathrm{~g}$ dry sample with $10 \mathrm{ml}$ ultrapure water at $25{ }^{\circ} \mathrm{C}$ and $350 \mathrm{rpm}$ stirring for 10 minutes, then filtered with a 0,45 micrometer size microfilter. Filtrates were analsed with ion chromatography. According to results of analysis based on five paralell measurements sodium cation and chloride, hydroxide, nitrate, phosphate and hydrogencarbonate anions are present in the washing water samples.

Chemical composition of the solid phase sludges were also determined by the fusion of the solid phases using potassium-hydroxide fusion and hydrochloric acid dissolution and sodium-peroxyde-sodium-hdroxide fusion and hydrochlorid acid dissolution.

Fusion using potassium hydroxide was completed with $\sim 1 \mathrm{~g}$ dry sludge mixed with $5 \mathrm{~g}$ potassium-hydroxide and heated for 30 minutes and after cooling dissolved in $50 \mathrm{ml}$ conc. 
$\mathrm{HCl}$ and $50 \mathrm{ml}$ ultrapure water. The determined potassium content was recalibrated using the potassium content of washing water samples, supposing that all potassium content is soluble in water. The total ionic content of the sludge samples P3-2 and P4-2 was calculated by summing the ionic contrations determined by wasing water and fusion solution analysis. The equivalent concentrations of the anions were calculated according to the distribution af the anions in the centrifuged supernatants of samples P3-2 and P4-2 and to the distributions of the anions in the washing water of sample P5-2.

The variances of the five repeated analysis results of this fusion was between $0,4-39 \%$ for the different ionic components.

For each sludge sample we completed also a sodium-peroxide-sodium-hydroxide fusion and a hydrochloric acid dissolution too. In the fusion process we mixed $\sim 0.25 \mathrm{~g}$ dry sludge with a mixture of $1.5 \mathrm{~g}$ sodium-peroxide and $1 \mathrm{~g}$ sodium-hydroxide and heated for 15 minutes at $600{ }^{\circ} \mathrm{C}$. After cooling the residue was dissolved with a mixture of $50 \mathrm{ml} \mathrm{cc}$. $\mathrm{HCl}$ and $50 \mathrm{ml}$ ultrapure water. Solutions were analyzed by ion chromatography. The variances of the five repeated analysis results of this fusion was significantly higher (23-87\%) then in case of the potassium.hydroxide based fusion, so we used the results of the smaller variances.

Results are summarized in Table 7.

a) P3-2

\begin{tabular}{|c|c|c|c|c|c|}
\hline \multicolumn{6}{|c|}{ Cations } \\
\hline & \multicolumn{3}{|c|}{$\mathrm{KOH}$ fusion+HCL } & \multicolumn{2}{|c|}{ total (supernatant+fusion) } \\
\hline & mg/g dry sludge & $\mathrm{mg} / \mathrm{l}$ sludgep & mekv/l sludge & mekv/l sludge & mg/l sludge \\
\hline $\mathrm{Na}$ & 200.59 & 17016.05 & 435.17 & 3790.07 & 87132.97 \\
\hline $\mathrm{NH}_{4}$ & & 0 & 0 & 0 & 0 \\
\hline $\mathrm{K}$ & 3.83 & 324.89 & 8.31 & 121.00 & 4731.58 \\
\hline $\mathrm{Mg}$ & 18.82 & 1596.50 & 131.37 & 131.37 & 1596.50 \\
\hline $\mathrm{Ca}$ & 62.42 & 5295.08 & 264.22 & 264.22 & 5295.09 \\
\hline $\mathrm{Mn}$ & 281.28 & 23860.98 & 1963.46 & 1963.46 & 53934.36 \\
\hline Sum & 285.66 & 24232.54 & 839.07 & 4306.67 & 98756.14 \\
\hline \multicolumn{6}{|c|}{$\begin{array}{l}\text { Anions } \\
\text { total equivalent capacity ditributed according to supernatant distribution }\end{array}$} \\
\hline $\mathrm{F}$ & - & 12.34 & 0.64 & 3.31 & 63.07 \\
\hline $\mathrm{Cl}$ & - & 92.31 & 2.60 & 13.30 & 471.59 \\
\hline $\mathrm{NO}_{3}$ & - & 7225.88 & 116.53 & 595.33 & 36913.83 \\
\hline $\mathrm{PO}_{4}$ & - & 53.29 & 1.68 & 8.60 & 272.26 \\
\hline $\mathrm{SO}_{4}$ & - & 312.03 & 6.49 & 33.18 & 1594.07 \\
\hline $\mathrm{OH}$ & - & 5383.97 & 316.70 & 1617.90 & 27504.34 \\
\hline $\mathrm{CO}_{3}$ & - & 11950.68 & 398.35 & 2035.02 & 61050.69 \\
\hline Sum & - & 25030.54 & 843.03 & 4306.675 & 127869.90 \\
\hline
\end{tabular}


b) P4-2

\begin{tabular}{|c|c|c|c|c|c|}
\hline \multicolumn{6}{|c|}{ Cations } \\
\hline & \multicolumn{3}{|c|}{$\mathrm{KOH}$ fusion $+\mathrm{HCl}$} & \multicolumn{2}{|c|}{ total (supernatant+fusion) } \\
\hline & mg/g dry sludge & mg/l sludge & mekv/l sludge & mekv/l sludge & mg/lsludge \\
\hline $\mathrm{Na}$ & 39.04 & 4199.53 & 182.67 & 196.20 & 4510.73 \\
\hline $\mathrm{NH}_{4}$ & 0 & 0 & 0 & 0 & 0 \\
\hline K & 0 & 0 & 0 & 0 & 0 \\
\hline $\mathrm{Mg}$ & 11.12 & 1196.18 & 98.43 & 98.43 & 1196.18 \\
\hline $\mathrm{Ca}$ & 68.49 & 7367.47 & 367.64 & 367.64 & 7367.47 \\
\hline $\mathrm{Mn}$ & 136.66 & 14700.52 & 267.58 & 267.58 & 7350.26 \\
\hline Sum & 118.65 & 12763.18 & 648.74 & 662.27 & 13074.38 \\
\hline \multicolumn{6}{|c|}{$\begin{array}{l}\text { Anions } \\
\text { total equivalent capacity ditributed according to supernatant distribution }\end{array}$} \\
\hline $\mathrm{F}$ & - & 0 & 0 & 0 & 0 \\
\hline $\mathrm{Cl}$ & - & 348.30 & 9.82 & 10.05 & 356.30 \\
\hline $\mathrm{NO}_{3}$ & - & 1741.50 & 28.08 & 28.73 & 1781.50 \\
\hline $\mathrm{PO}_{4}$ & - & 531.16 & 16.78 & 17.16 & 543.36 \\
\hline $\mathrm{SO}_{4}$ & - & 161.09 & 3.35 & 3.43 & 164.79 \\
\hline $\mathrm{OH}$ & - & 0 & 0 & 0 & 0 \\
\hline $\mathrm{CO}_{3}$ & - & 11479.55 & 382.65 & 391.44 & 11743.22 \\
\hline $\mathrm{HCO}_{3}$ & - & 12612.84 & 206.71 & 211.46 & 12902.54 \\
\hline
\end{tabular}

c) P5-2

\begin{tabular}{|c|c|c|c|c|}
\hline \multicolumn{5}{|c|}{ Cations } \\
\hline & \multicolumn{3}{|c|}{$\mathrm{KOH}$ fusion+HCl } & Total(fusion) \\
\hline & $\begin{array}{c}\mathrm{mg} / \mathrm{g} \\
\text { dry sludge }\end{array}$ & $\begin{array}{l}\mathrm{mg} / 1 \\
\text { sludge }\end{array}$ & $\begin{array}{l}\text { mekv/1 } \\
\text { sludge }\end{array}$ & $\begin{array}{l}\text { mekv } / 1 \\
\text { sludge }\end{array}$ \\
\hline $\mathrm{Na}$ & 29.29 & 11704.87 & 509.13 & 509.13 \\
\hline $\mathrm{NH}_{4}$ & 0 & 0 & 0 & 0 \\
\hline $\mathrm{K}$ & 0 & 0 & 0 & 0 \\
\hline $\mathrm{Mg}$ & 6.967 & 2784.153 & 229.10 & 229.10 \\
\hline $\mathrm{Ca}$ & 60.99 & 24372.82 & 1216.21 & 1216.21 \\
\hline $\mathrm{Mn}$ & 138.75 & 55447.28 & 1009.27 & 1009.27 \\
\hline Sum & 97.247 & 38861.85 & 1954.44 & 1954.44 \\
\hline \multicolumn{5}{|c|}{$\begin{array}{l}\text { Anions } \\
\text { ed according to washing water distribution }\end{array}$} \\
\hline $\mathrm{F}$ & - & 0 & 0 & 0 \\
\hline $\mathrm{Cl}$ & - & 1535.89 & 43.32 & 43.32 \\
\hline $\mathrm{NO}_{3}$ & - & 1000.38 & 16.13 & 16.13 \\
\hline $\mathrm{PO}_{4}$ & - & 21549.04 & 680.70 & 680.70 \\
\hline $\mathrm{SO}_{4}$ & - & 3731.21 & 77.69 & 77.69 \\
\hline $\mathrm{OH}$ & - & 0 & 0 & 0 \\
\hline $\mathrm{CO}_{3}$ & - & 0 & 0 & 0 \\
\hline $\mathrm{HCO}_{3}$ & - & 69352.12 & 1136.60 & 1136.60 \\
\hline Sum & - & 97168.64 & 1954.44 & 1954.44 \\
\hline
\end{tabular}

Table 7. Ionic composition of solid sludges using $\mathrm{KOH}$ fusion and the total sludge composition 
We determined also the the undissolved oxalate content of the sludges by treating the samples first with cc. $\mathrm{HCl}$ for the dissolution of iron complexes, followed with a cc. nitric acid dissolution. The undissolved oxalate content of the samples P3-2, P4-2 and P5-2 was $4.177,6.848,23.362 \mathrm{meq} / 1$ accordingly.

The EDTA content of the centrifuged supernatants were determined with ion chromatography with the method suggested by analysts (Krokidis et al.,2005). The EDTA content (as $\mathrm{Na}_{2} \mathrm{H}_{2}-\mathrm{EDTA}^{*} 2 \mathrm{H}_{2} \mathrm{O}$ ) was for centrifuged supernatant samples P3-2 and P4-2 10.86 and $12.82 \mathrm{mmol} / \mathrm{l}$ accordingly. The iron and manganese content of the sludge samples were determined by AAS.

The borate content of the centrifuged supernate samples P3-2 and P4-2 was determined also with ion chromatography with the method suggested by analysts (Tapparo et. al.,1998). The borate content was for centrifuged supernatant samples P3-2 and P4-2 164.35 and $1.172 \mathrm{~g} / 1$ accordingly.

The sludge composition was then calculated based on the ion chromatographic and titrimetric analysis of the supernatant, washing water, fusion samples and on the ICP-MS analysis. The calculated sludge compositions are summerized in Table 8.

a) P3-2

\begin{tabular}{|c|c|c|c|}
\hline Composition & mekv/l sludge & mmol/l sludge & mg/l sludge \\
\hline $\mathrm{NaOH}$ & 1618 & 1618 & 63084.53 \\
\hline $\mathrm{Na}_{2} \mathrm{CO}_{3}$ & 2035 & 1017.5 & 107843.6 \\
\hline $\mathrm{NaNO}_{3}$ & 137 & 137 & 11644.27 \\
\hline $\mathrm{KNO}_{3}$ & 121 & 121 & 16723.8 \\
\hline $\mathrm{Ca}\left(\mathrm{NO}_{3}\right)_{2}$ & 264 & 132 & 13211.77 \\
\hline $\mathrm{MgCO}$ & 125 & 62.5 & 2634.819 \\
\hline sum of ionic & 4300 & 3088 & 215142.8 \\
\hline $\mathrm{Fe}(\mathrm{OH})_{3}$ & 2279.7 & 759.9 & 81209 \\
\hline $\mathrm{Mn}(\mathrm{OH})_{2}$ & 109.7 & 54.85 & 4879.5 \\
\hline
\end{tabular}

b) P4-2

\begin{tabular}{|c|c|c|c|}
\hline Composition & mekv/l sludge & mmol/l sludge & mg/l sludge \\
\hline $\mathrm{NaNO}_{3}$ & 28.73 & 28.73 & 2441.898 \\
\hline $\mathrm{Na}_{2} \mathrm{CO}_{3}$ & 163.47 & 81.735 & 8662.995 \\
\hline $\mathrm{CaCO}_{3}$ & 227.93 & 113.965 & 11406.67 \\
\hline $\mathrm{Ca}\left(\mathrm{HCO}_{3}\right)_{2}$ & 139.71 & 69.855 & 11324.5 \\
\hline $\mathrm{Mg}\left(\mathrm{HCO}_{3}\right)_{2}$ & 71.79 & 35.895 & 5252.853 \\
\hline $\mathrm{MgCl}_{2}$ & 10.05 & 5.025 & 478.4353 \\
\hline $\mathrm{Mg}_{3}\left(\mathrm{PO}_{4}\right)_{2}$ & 17.16 & 2.86 & 751.7733 \\
\hline $\mathrm{MgSO}_{4}$ & 3.43 & 1.715 & 206.4219 \\
\hline $\mathrm{Sum} \mathrm{of} \mathrm{ionic}$ & 662.27 & 339.78 & 40525.54 \\
\hline $\mathrm{Fe}(\mathrm{OH})_{3}$ & 6134.34 & 2044.78 & 218523.6 \\
\hline $\mathrm{Mn}(\mathrm{OH})_{2}$ & 581.18 & 290.59 & 25848.81 \\
\hline
\end{tabular}


c) $\mathrm{P} 5-2$

\begin{tabular}{|c|c|c|c|}
\hline Composition & mekv/l sludge & mol/l sludge & mg/l sludge \\
\hline $\mathrm{NaCl}$ & 43.32 & 43.32 & 2531.742 \\
\hline $\mathrm{NaNO}_{3}$ & 16.13 & 16.13 & 1370.965 \\
\hline $\mathrm{Na}_{3} \mathrm{PO}_{4}$ & 449.68 & 149.8933 & 24573.63 \\
\hline $\mathrm{Ca}_{3}\left(\mathrm{PO}_{4}\right)_{2}$ & 231 & 38.5 & 11942.04 \\
\hline $\mathrm{Ca}\left(\mathrm{HCO}_{3}\right)_{2}$ & 985.21 & 492.605 & 79858.36 \\
\hline $\mathrm{Mg}\left(\mathrm{HCO}_{3}\right)_{2}$ & 151.4 & 75.7 & 11077.89 \\
\hline $\mathrm{MgSO}$ & 77.71 & 38.855 & 4676.689 \\
\hline sum of ionic & 1954.45 & 855.0033 & 136031.3 \\
\hline $\mathrm{Fe}(\mathrm{OH})_{3}$ & 4572.75 & 1524.25 & 162895.3 \\
\hline $\mathrm{Mn}(\mathrm{OH})_{2}$ & 12.742 & 6.371 & 566.73 \\
\hline
\end{tabular}

Table 8. The calculated composition of the sludge samples

\section{Radiochemical composition}

The radiochemical composition of the sludge samples was determined using gamma- and alpha-spektrometry and liquid scintillation measurements. For the gamma-spektrometry we used an ORTEC Model GMX25P4-76-C, Gamma-X HPGe Coaxial Detector with a CarbonFiber window, connected to a multichannel anlyser ORTEC DSPEC-jr-2.0, the spectra were measured with $100 \mathrm{~cm}^{3}$ poliethylene sample with a $3600 \mathrm{sec}$ counting time. Spectra were evaluated with a Gamma Vision - 32 code. The results show, that in the P3-2 sludge $\sim 99,5 \%$ of the gamma-activity is from ${ }^{137} \mathrm{Cs},{ }^{134} \mathrm{Cs}$ and ${ }^{60} \mathrm{Co}$ isotopes. The centrifuged supernatant contains $92-92,7 \%$ of the cesium, $14,26 \%$ of the cobalt and $91,35 \%$ of the total gamma-activity. In the P4-2 sludge $\sim 99,4 \%$ of the gamma-activity is from ${ }^{60} \mathrm{Co}$ and ${ }^{137} \mathrm{Cs}$, ${ }^{134} \mathrm{Cs}{ }^{54} \mathrm{Mn}$ isotopes. The centrifuged supernatant contains only $0.62 \%$ of the total gammaactivity. After fusion of the solid parts of the sludges for the P3-2 sample $97 \%$ of the gamma activity is due to ${ }^{137} \mathrm{Cs}$ and ${ }^{60} \mathrm{Co}$, while for the $\mathrm{P} 4-2$ sample $89 \%$ of the gamma-activity is due to ${ }^{60} \mathrm{Co}, 5,7 \%{ }^{137} \mathrm{Cs}$ and there is also ${ }^{54 \mathrm{Mn}}$ isotope present. P5-2 sample contains less activity of which $50,6 \%$ is ${ }^{60} \mathrm{Co}$ and conatins ${ }^{54} \mathrm{Mn}$ and ${ }^{137} \mathrm{Cs}$ isotopes too.

Finally we determined the alpha- and beta-emitting isotopes in the samples too using preconcentration and salt removal techniques.For the alpha-activity measurements we used TRU columns and alpha-spectrometry and for the determination of beta-activity liquid scintillation technique. Detailed description of these measurements will be submitted later. Resultst for the $\mathrm{KOH}$ fusion samples radionuclide analysis are shown in Table 9.

\begin{tabular}{|c|c|c|c|c|c|c|c|c|}
\hline \multirow[b]{2}{*}{ Isotope } & \multicolumn{2}{|c|}{ Sample P-3-2 } & \multirow[b]{2}{*}{ Isotope } & \multicolumn{2}{|c|}{ Sample P-4-2 } & \multirow[b]{2}{*}{ Isotope } & \multicolumn{2}{|c|}{ Sample P-5-2 } \\
\hline & $\begin{array}{c}\text { Act. conc. } \\
\mathrm{Bq} / \mathrm{kg}\end{array}$ & $\begin{array}{c}\sigma \\
\mathrm{Bq} / \mathrm{kg}\end{array}$ & & $\begin{array}{c}\text { Act. conc. } \\
\mathrm{Bq} / \mathrm{kg}\end{array}$ & $\begin{array}{c}\sigma \\
\mathrm{Bq} / \mathrm{kg}\end{array}$ & & $\begin{array}{l}\text { Act. conc. } \\
\mathrm{Bq} / \mathrm{kg}\end{array}$ & $\begin{array}{c}\sigma \\
\mathrm{Bq} / \mathrm{kg}\end{array}$ \\
\hline $234 \mathrm{U}$ & & & $234 \mathrm{U}$ & & & $234 \mathrm{U}$ & & \\
\hline $238 \mathrm{U}$ & & & $238 \mathrm{U}$ & & & $238 \mathrm{U}$ & & \\
\hline $239,240 \mathrm{Pu}$ & 78.5 & \pm 8.68 & $239,240 \mathrm{Pu}$ & 549 & \pm 21.1 & $239,240 \mathrm{Pu}$ & 127 & \pm 12.7 \\
\hline $238 \mathrm{Pu}$ & 78.1 & \pm 8.79 & ${ }^{238} \mathrm{Pu}$ & 429 & \pm 18.5 & $238 \mathrm{Pu}$ & 194 & \pm 15.7 \\
\hline${ }^{241} \mathrm{Am}$ & 73.8 & \pm 3.78 & ${ }^{241} \mathrm{Am}$ & 771 & \pm 16.5 & ${ }^{241} \mathrm{Am}$ & 99.8 & \pm 8.82 \\
\hline${ }^{244} \mathrm{Cm}$ & 11.9 & \pm 1.47 & ${ }^{244} \mathrm{Cm}$ & 124 & \pm 5.64 & ${ }^{244} \mathrm{Cm}$ & 54.5 & \pm 5.68 \\
\hline $90 \mathrm{Sr}$ & 21500 & \pm 1080 & $90 \mathrm{Sr}$ & 10200 & 512 & $90 \mathrm{Sr}$ & 20700 & \pm 1040 \\
\hline
\end{tabular}

Table 9. The measured alpha- and beta-activities of the fused samples with $\mathrm{KOH}$ 


\section{Conclusion}

The evaporator bottom residue in the NPP Paks contains high inactive salt content $\left(\sim 400 \mathrm{~g} / \mathrm{dm}^{3}\right)$ with trace amount of radioactive fission and activation products. The separation of the bulk borate and nitrate from the radioactive minor components is of great importance before solidification. The modified separation technology produces clean crystals without radioactive pollutants above the "unconditional" clearance limits. The final volume reduction factor is higher then 1000 .

There are some tanks at the power plant containing sludge type radioactive waste containing more or less liquid phase too. The general physical and chemical charactersitics (density, $\mathrm{pH}$, total solid, dissolved solid etc.) and chemical and radiochemical composition of these sludges are important information for volume reduction and solidification treatment of theese wastes. Based on the literature sources we have investigated and constructed a complex analysis system for the radioactive sludge and supernatant analysis, including the physical, as well as the chemical and radiochemical analysis methods. Using well known analysis techniques as ion chromatography, ICP-MS, AAS, gamma-and alfaspectrometry and chemical alkaline fusion digestion and acidic dissolution methods we could analyze the main inorganic, organic and radioactive components of the sludges and supernatants. Determination of the mass and charge balance for the sludge samples were more difficult then for the supernantant samples. Not only are there assumptions required about the chemical form and the oxidation state of the species present in the sludge, but many of the compounds in the sludge are mixed oxides which are not directly measured. Also, the sludge is actually a slurry with a high water content. The interstitial liquid is in close contact with the sludge, and there are many ionic solubility equilibriums. The anion data for the sludge samples are based on the water soluble anions that would be available to a water wash. The water wash would not account for the insoluble hydroxides, carbonates, and mixed oxides present. The insoluble species do not contribute to the charge balance, and the cation charge is not used in the calculation. Most of the nitrate reported for the sludge is due to the interstitial liquid. Considering the limitations of these calculations, the mass balance was within the analytical error $( \pm 20 \%)$ for the sludge samples. There were three sample preparation methods used to investigate the total anion content of the sludge samples, which included water leach, potassium-hydroxide and/or sodium peroxide/sodium hydroxide fusion and acidic dissolution.

\section{References}

Ceo, R. N., M. B. Sears, J. T. Shor (1990). Physical characterisation of Radioactive Sludges in Selected Melton Valley and Evaporator Facility storage Tanks. ORNL/TM - 11653

Krokidis, A.A., et. al. (2005). EDTA Determination in Pharmaceutical Formulations and Canned Foods Based on Ion Chromatography with Supressed Conductimetric Detection. Analytica Chimica Acta, 535, pp. 57-63

Patzay, G.,et. al. (2006). Radioactive wastewater treatment using a mixture of TANNIX sorbent and VARION mixed bed ion exchange resin, International Journal of Nuclear Energy Science and Technology (IJNEST), 2(4), 328-341, 
Tapparo, A., P. Pastore, G. Bombi (1998). Ion chromatographic Determination of Borate in Aqueous Samples Together with Other Common Anions, Analyst, August, Vol. 123 (1771-1773) 


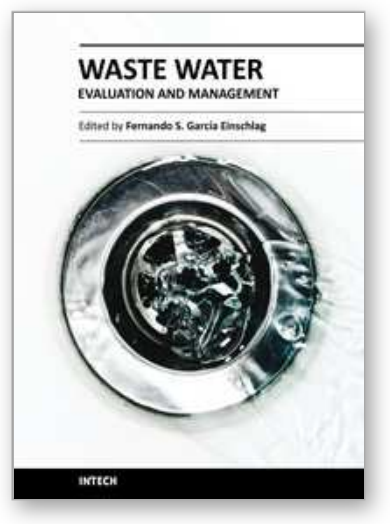

\author{
Waste Water - Evaluation and Management \\ Edited by Prof. Fernando Sebastiã $i n$ GarcÃa Einschlag
}

ISBN 978-953-307-233-3

Hard cover, 470 pages

Publisher InTech

Published online 01, April, 2011

Published in print edition April, 2011

Fresh water resources are under serious stress throughout the globe. Water supply and water quality degradation are global concerns. Many natural water bodies receive a varied range of waste water from point and/or non point sources. Hence, there is an increasing need for better tools to asses the effects of pollution sources and prevent the contamination of aquatic ecosystems. The book covers a wide spectrum of issues related to waste water monitoring, the evaluation of waste water effect on different natural environments and the management of water resources.

\title{
How to reference
}

In order to correctly reference this scholarly work, feel free to copy and paste the following:

György Pátzay, László Weiser, Ferenc Feil and Gábor Patek (2011). Analysis and Selective Treatment of Radioactive Waste Waters and Sludges, Waste Water - Evaluation and Management, Prof. Fernando Sebastî̃ in GarcÃa Einschlag (Ed.), ISBN: 978-953-307-233-3, InTech, Available from:

http://www.intechopen.com/books/waste-water-evaluation-and-management/analysis-and-selective-treatmentof-radioactive-waste-waters-and-sludges

\section{INTECH}

open science | open minds

\section{InTech Europe}

University Campus STeP Ri

Slavka Krautzeka 83/A

51000 Rijeka, Croatia

Phone: +385 (51) 770447

Fax: +385 (51) 686166

www.intechopen.com

\section{InTech China}

Unit 405, Office Block, Hotel Equatorial Shanghai

No.65, Yan An Road (West), Shanghai, 200040, China

中国上海市延安西路65号上海国际贵都大饭店办公楼405单元

Phone: +86-21-62489820

Fax: +86-21-62489821 
(C) 2011 The Author(s). Licensee IntechOpen. This chapter is distributed under the terms of the Creative Commons Attribution-NonCommercialShareAlike-3.0 License, which permits use, distribution and reproduction for non-commercial purposes, provided the original is properly cited and derivative works building on this content are distributed under the same license. 